\title{
Nitrogén, réz és molibdén kölcsönhatása a zabra (Avena sativa L.)
}

\author{
KÁDÁR Imre \\ MTA ATK Talajtani és Agrokémiai Intézet, Budapest
}

\section{Bevezetés és irodalmi áttekintés}

A zab föként a hüvösebb, csapadékos éghajlatú északi országok gabonanövénye. Öshazája Elö-Ázsia. A bronzkortól termesztett és ismert. Értékes stratégiai termény volt évszázadokon át a hadsereg, a lovasság számára. Ahol a nyári aszály kifejezett, ott az árpa helyettesíti. Nem hatol annyira északra, mint az árpa, mert a tenyészideje hosszú. Ukrajnában a leszosztyepp-övezet növénye. A Bajkálon túl Szibériában már csak a tavaszi zab vethető a zordabb klíma miatt, az ősziek visszaszorulnak. Hazánkban a Dunántúlon és az Északi-középhegység csapadékosabb tájain terem. Az 1800-as évek közepéig mintegy 250 ezer hektáron termesztettük, majd a gépi vonóerő elterjedésével, illetve a lótartás visszaszorulásával területe 1/10-ére csökkent (CSERHÁTI 1901, GRÁBNER 1948).

Esős években, amikor az árpa és a búza sínylődik, a zab a rozzsal együtt buján fejlödik. Száraz tavaszon viszont alacsony és ritka marad. A nyári aszály után pedig sok a léha zab. A tavaszi árpával együtt a legkorábban február 25 - március 15. között vethető és a legkésőbb júliusban aratható. Jó gyomelnyomó képességgel rendelkezik. Szalmája kedvelt takarmány és silózási adalék a marha és a juh számára a tavaszi árpa szalmájához hasonlóan. A júliusi késői érés ellenére a szalma még általában zöld. Ezért volt ajánlott korábban a kétmenetes aratás, amikor a lekaszált állomány 1-2 napig a tarlón száradt (ANTAL 2000, JAKUSKIN 1947, RADICS 2003).

Erőteljes gyökérzete hasznosítja a nyers talajok (gyeptörés, erdőirtás), kötöttebb termőhelyek tápelem és vízkészletét. Ideális számára a humuszban, nitrogénben, tápanyagban gazdag vályogtalaj. A többi gabonához viszonyítva főként $\mathrm{N}$-igényével tünik ki. Homokos és tőzeges talajon K-igényessé válik. A Nigényére utal, hogy a hagyományos szakirodalom szerint a legjobb termés az istállótrágyázott kapás után várható. Hasonlóképpen kedvező, ha a zab pillangós takarmány vagy hüvelyes után következik (LÁNG 1976, MitrofANOV és MitrofanOVA 1970, KATALÜMOV 1960).

A szalma tömege általában 1,5-2,0-szerese a mag tömegének. A pelyvával együtt nemcsak értékes szálastakarmány, hanem a papír és keményítő gyártásának alapanyaga is. Zölden önmagában vagy bükkönnyel vetve jelentős keményítóértékével és emészthető fehérjetartalmával tünik ki. A magtermés sokoldalúan hasznosítható. Azon túl, hogy a lovak, valamint a növedék és tejelő állatok kiváló koncentrált abraktakarmánya, humán táplálkozásra és élelmiszeripari feldolgozásra is alkalmas. Gazdag keményítőben, fehérjében, zsírban, Evitaminban. A zabpehely, zabliszt könnyen emészthető erőtápszer/csecsemőtápszer, 
melynek jelentős Ca és P készlete a csontképzést is segíti. Magjából néhol sört is erjesztettek. A mag 13-14\% fehérjét, 7-8\% nyerszsírt és 60-70\% N-mentes kivonható anyagot tartalmazhat (PRIMOST 1965, MENGEL 1976, PRJANISNYIKOV 1931, SCHMIDT 1961).

Agrotechnikája gyakorlatilag a tavaszi árpáéval egyező. A kora márciusi vetés 4-5 cm mélyre történik 55-60 db szem/fm, gabonasor-távra 4-5 millió csíra/ha, illetve 130-150 $\mathrm{kg} \cdot \mathrm{ha}^{-1}$ vetőmagnormával. A hektolitersúly 40-60 $\mathrm{kg}$, az ezermagtömeg 20-40 g körüli. A korábbi hazai irodalom 1-2 $\mathrm{t} \cdot \mathrm{ha}^{-1}$ szemtermésekröl tudósít általában (CSERHÁTI 1901, GRÁBNER 1948, MURAKÖZI 1958). ANTAL (2000) ÉS JOLÁNKAI (2005) az újabb termesztési körülmények között a 2-6 th ha ${ }^{-1}$ termésszinteket feltételez a termőhelyek függvényében. Megemlíthető, hogy kiugró termésekről ad számot JAKUSKIN (1947) a korábbi Szovjetunió területén, aki szerint Novoszibirszk körzetében a „Trudovnyik” kolhoz $7 \mathrm{t} \cdot \mathrm{ha}^{-1}$ feletti szemterméseket ért el.

A hazai növénytermesztési szakirodalom a zab fajlagos, $1 \mathrm{t}$ szem $+\mathrm{a}$ hozzátartozó melléktermés elemigényét 28-12-29-6-2=N- $\mathrm{P}_{2} \mathrm{O}_{5}-\mathrm{K}_{2} \mathrm{O}-\mathrm{CaO}-\mathrm{MgO} \mathrm{kg}-$ ban jelöli meg átlagosan. Saját kísérletünkben, mezöföldi mészlepedékes csernozjom talajon, a mütrágyázás függvényében mért fajlagos elemtartalom jól egyezett az ANTAL (2000) ÉS JOLÁNKAI (2005) által ajánlottakkal és az alábbi értékek között ingadozott: N-23-33 kg, $\mathrm{P}_{2} \mathrm{O}_{5} 9-16$ kg K2 20 24-36 kg, CaO 5-10 kg, MgO 3-5 kg (KÁDÁR és LÁSZTITY 1997B). Az emelkedett Ca és Mg fajlagos mutató esetünkben a meszes termőhelyre vezethető vissza. A viszonylag kedvező csapadékos évben a szem 4-6 th ha ${ }^{-1}$, szalma 4-7 th ha ${ }^{-1}$, az összes földfeletti biomassza 8-13 th ha ${ }^{-1}$ között változott az NPK adagok nyomán (KÁDÁR ÉS LÁSZTITY 1997A).

\section{Anyag és módszer}

A N x Cu kölcsönhatásokat vizsgáló kéttényezős kísérletet 1988 tavaszán állítottuk be az MTA ATK TAKI nagyhörcsöki kísérleti telepén. A kísérlet talaja löszön képződött meszes csernozjom, mely a kísérlet beállítása előtt 1988 március elején végzett talajvizsgálataink szerint mintegy $5 \% \mathrm{CaCO}_{3}$-ot és $3 \%$ humuszt tartalmazott a szántott rétegben. A pH(KCl) $=7,3$; az AL- $\mathrm{P}_{2} \mathrm{O}_{5} 128 \mathrm{mg} \cdot \mathrm{kg}^{-1}, \mathrm{AL}-$ $\mathrm{K}_{2} \mathrm{O} 243 \mathrm{mg} \cdot \mathrm{kg}^{-1}$, KCl-Mg $150-180 \mathrm{mg} \cdot \mathrm{kg}^{-1}$, az EDTA-Mn $127 \mathrm{mg} \cdot \mathrm{kg}^{-1}$, az EDTACu 2-3 mg. $\mathrm{kg}^{-1}$, EDTA-Zn 1-2 $\mathrm{mg} \cdot \mathrm{kg}^{-1}$ értékekkel jellemezhetők. A KCl-oldható $\mathrm{NH}_{4}-\mathrm{N}$ 9, $\mathrm{NO}_{3}-\mathrm{N} 12 \mathrm{mg} \cdot \mathrm{kg}^{-1}$ a feltalajban. A BuZÁs et al. (Szerk.: 1979) által elfogadott módszerek és határértékek alapján ezek az adatok a talaj jó $\mathrm{Ca}, \mathrm{Mg}, \mathrm{K}$, $\mathrm{Mn}$; kielégítő $\mathrm{Cu}$, valamint gyenge $\mathrm{P}$ és $\mathrm{Zn}$ ellátottságáról tanúskodnak. A talajvíz szintje 13-15 m mélyen helyezkedik el, a terület aszályérzékeny. Éghajlata az Alföldéhez hasonlóan szárazságra hajló, átlagos középhőmérséklete $11^{\circ} \mathrm{C}$, éves átlagos csapadékösszege $576 \mathrm{~mm}$.

A kísérlet osztott parcellás (split-plot) elrendezésü $4 \mathrm{Nx} 3 \mathrm{Cu}=12$ kezeléssel és 3 ismétléssel, összesen 36 parcellával. A parcellák mérete 4,9 x $15=73,5 \mathrm{~m}^{2}$ volt. Az 
alaptrágyázás évente $100 \mathrm{~kg} \cdot \mathrm{ha}^{-1} \mathrm{P}_{2} \mathrm{O}_{5}$ és $100 \mathrm{~kg} \cdot \mathrm{ha}^{-1} \mathrm{~K}_{2} \mathrm{O}$ adagot jelentett szuperfoszfát és kálisó formájában. A N-t 25\%-os pétisó $\left(\mathrm{Ca}^{-} \mathrm{NH}_{4} \mathrm{NO}_{3}\right)$, a $\mathrm{Cu}$ trágyát 25,5\%-os $\mathrm{CuSO}_{4} \times 5 \mathrm{H}_{2} \mathrm{O}$ formában alkalmaztuk. A PK mütrágyákat és a $\mathrm{N}$ felét az elővetemény lucerna törésére szórtuk ki 1987 öszén és leszántottuk, míg a N másik felét és a $\mathrm{CuSO}_{4}$ trágyát 1988 tavaszán kevertük a talajba vetés előtt. Az 5 . évben 1992 tavaszán a 15 m hosszú parcellákat megfeleztük és egy 1 m-es úttal elválasztottuk. Az osztott parcellás (split-plot) elrendezésủ kísérletünk háromtényezőssé vált $4 \mathrm{~N} \times 3 \mathrm{Cu} \times 2 \mathrm{Mo}=24$ kezeléssel $\times 3$ ismétléssel $=72$ parcellával. A felezett parcellákra $48 \mathrm{~kg} \cdot \mathrm{ha}^{-1}$ Mo-t szórtunk ki N-fejtrágyával egyidőben. A Mo trágyát $\left(\mathrm{NH}_{4}\right)_{6} \mathrm{Mo}_{7} \mathrm{O}_{24} \cdot 4 \mathrm{H}_{2} \mathrm{O}$ formában adagoltuk. A N és a Mo sókat a következő napok csapadéka a talajba mosta. Tehát a Cu-trágyázás 1988-ban, Mo-trágyázás 1992-ben történt egyszeri alkalommal. A N, P és K mütrágyákat évente adtuk.

Vizsgált tényezők az alábbiak:

\begin{tabular}{|c|c|c|}
\hline $\begin{array}{l}\quad \begin{array}{l}\text { 1. tényezö } \\
\text { (fóparcellák): }\end{array} \\
\mathrm{N}_{0}=0 \mathrm{~kg} \cdot \mathrm{ha}^{-1} \cdot \mathrm{é}^{-1} \mathrm{~N} \\
\mathrm{~N}_{1}=100 \mathrm{~kg} \cdot \mathrm{ha}^{-1} \cdot \mathrm{é}^{-1} \mathrm{~N} \\
\mathrm{~N}_{2}=200 \mathrm{~kg} \cdot \mathrm{ha}^{-1} \cdot \mathrm{é}^{-1} \mathrm{~N} \\
\mathrm{~N}_{3}=300 \mathrm{~kg} \cdot \mathrm{ha}^{-1} \cdot \mathrm{év}^{-1} \mathrm{~N}\end{array}$ & $\begin{aligned} & \text { 2. tényezö (alparcellák): } \\
\mathrm{Cu}_{0}= & \mathrm{kontroll} \\
\mathrm{Cu}_{1}= & 50 \mathrm{~kg} \cdot \mathrm{ha}^{-1} \mathrm{Cu} \text { 1988-ban } \\
\mathrm{Cu}_{2}= & 100 \mathrm{~kg} \cdot \mathrm{ha}^{-1} \mathrm{Cu} \text { 1988-ban }\end{aligned}$ & $\begin{array}{c}\frac{\text { 3.tényezö }}{\text { (al-alparcellák): }} \\
\mathrm{Mo}_{0}=\text { kontroll } \\
\mathrm{Mo}_{1}=48 \mathrm{~kg} \cdot \mathrm{ha}^{-1} 1992 \text {-ben }\end{array}$ \\
\hline
\end{tabular}

\section{A tartamkísérletben termesztett növények}

A kísérlet 1. évében 1988-ban tavaszi árpa, 1989-ben őszi búza, 1990-ben őszi árpa, 1991-ben kukorica, 1992-ben tritikále, 1993-ban burgonya volt a termesztett növény. Jelen cikk az 1994-ben termesztett zab eredményeit mutatja be. A növényi sorrendet a 16 év folyamán az 1. táblázat tünteti fel.

\section{1. táblázat}

A N x Cu tartamkísérlet növényi sorrendje 1988-2003 között. (Mészlepedékes csernozjom vályogtalaj, Nagyhörcsök, Mezöföld)

\begin{tabular}{|c|c|c|c|c|c|}
\hline $\begin{array}{c}\text { Kísérlet } \\
\text { éve }\end{array}$ & $\begin{array}{c}\text { Növényfaj } \\
\text { (forgó) }\end{array}$ & $\begin{array}{c}\text { Fajta } \\
\text { (hibrid) }\end{array}$ & $\begin{array}{c}\text { Kísérlet } \\
\text { éve }\end{array}$ & $\begin{array}{r}\text { Növényfaj } \\
\text { (forgó) }\end{array}$ & $\begin{array}{c}\text { Fajta } \\
\text { (hibrid) }\end{array}$ \\
\hline 1988 & tavaszi árpa & Opal & 1996 & lucerna & Szarvasi-1 \\
1989 & öszi búza & MV-15 & 1997 & lucerna & Szarvasi-1 \\
1990 & öszi árpa & MV-35 & 1998 & lucerna & Szarvasi-1 \\
1991 & kukorica & Pi 3732 & 1999 & lucerna & Szarvasi-1 \\
1992 & tritikále & Presto & 2000 & repce & Wester \\
1993 & burgonya & Desirée & 2001 & mák & Kék Duna \\
1994 & zab & Leanda & 2002 & napraforgó & IHNK hibrid \\
1995 & rozs & Kisvárdai-1 & 2003 & tavaszi árpa & Orbit \\
\hline
\end{tabular}




\section{Mintavétel és laboratóriumi vizsgálatok}

A parcellák nettó területéről bokrosodás végén és aratás előtt 4-4 fm, azaz $0,5 \mathrm{~m}^{2}$ területről földfeletti növénymintákat vettünk a kémiai analízis, a tömegmérés, az aratáskori szem/szalma, illetve szem/pelyva arányának megállapítása céljából. A növényi anyagokat $40-50^{\circ} \mathrm{C}$-on szárítottuk, majd finomra öröltuik. A minták laboratóriumi előkészítése a kísérleti telepen történt. Mintavételek előtt a növényállományt fejlettségre bonitáltuk 1-5 skálán. Aratás a parcellák nettó területéről, 7 × 2,1 = 14,7 $\mathrm{m}^{2}$ kombájnolt csíkokból nyert termést jelentette. Az 1000-szem súlyát 4 x $500 \mathrm{db}$ mag mérésével állapítottuk meg szintén parcellánként. Laboratóriumi vizsgálatok az MTA ATK Talajtani és Agrokémiai Intézetben történtek az alább ismertetett módszerekkel:

Növényelemzés: A bemért $0,5 \mathrm{~g}$ légszáraz anyaghoz $5 \mathrm{~cm}^{3} \mathrm{cc} \cdot \mathrm{HNO}_{3}+1 \mathrm{~cm}^{3}$ cc. $\mathrm{H}_{2} \mathrm{O}_{2}$ adagolása, majd 15 perces roncsolás a mikrohullámú berendezésben. Az ásványi elemek mérése ICP-AES készüléken. A $\mathrm{N}$ meghatározása: $0,5 \mathrm{~g}$ légszáraz anyaghoz $10 \mathrm{~cm}^{3}$ cc. $\mathrm{H}_{2} \mathrm{SO}_{4}+\mathrm{cc} \cdot \mathrm{H}_{2} \mathrm{O}_{2}$ szükség szerint adagolva az MSZ 20135(1999), illetve a módosított KJELDAHL (1891) eljárással.

Talajelemzés: A KCl + EDTA oldható Cu-tartalmat, valamint az $1 \mathrm{~mol} / \mathrm{L} \mathrm{KCl}$ kicserélhető $\mathrm{NH}_{4}-\mathrm{N}$ és $\mathrm{NO}_{3}-\mathrm{N}$ tartalmakat a MÉM NAK (1978), illetve BARANYAI ET AL. (1987) által ismertetett eljárásokkal vizsgáltuk. Az $\mathrm{NH}_{4}$-acetát+EDTA oldható ásványi elemeket LAKANEN és ERVIÖ (1971), a humuszt TYURIN (1937), az ammoniumlaktát+ecetsav oldható elemeket EGNÉR et al. (1960), az összes N-t az ISO 11261 (1995), illetve a módosított KJELDAHL (1891) által ismertetettek alapján határoztuk meg.

A zab vetésére március 3-án került sor. Az állományt bonitáltuk fejlettségre bokrosodás idején május 9-én, majd a fellépő vetésfehérítő bogár kártételére május 30-án. Aratás előtt július 21-én parcellánként 4-4 fm, azaz $0,5 \mathrm{~m}^{2}$ területről mintakévét vettünk a terméselemek vizsgálata, illetve a laborelemzés céljaira. A kísérletben alkalmazott agrotechnikai müveletekről és módszertani beavatkozásokról, illetve megfigyelésekről az 2. táblázat nyújt áttekintést.

Csapadékellátottság: Az elővetemény burgonya a talajt kiszárította. A burgonya szeptember eleji betakarítása és a zab március elejei vetése között eltelt 6 hónap alatt azonban összesen $367 \mathrm{~mm}$ csapadék hullott, mely a talaj vízkészletét pótolhatta. A zab tenyészideje alatt márciusban 13, áprilisban 50, májusban 35, júniusban 17, júliusban 22, azaz a 4,5 hónap alatt (140 nap) mindösszesen $137 \mathrm{~mm}$ eső esett 1994-ben. 


\section{2. táblázat}

Agrotechnikai müveletek és megfigyelések a zab kísérletben 1994-ben (Mészlepedékes csernozjom vályogtalaj, Nagyhörcsök, Mezőföld)

\begin{tabular}{|c|c|c|}
\hline Müveletek megnevezése & Időpontja & Egyéb megjegyzések \\
\hline 1.Öszi mütrágyázás $(\mathrm{N}, \mathrm{P}, \mathrm{K})$ & 1993.11.08. & Parcellánként kézzel \\
\hline 2.Egyirányú szántás & 1993.11.08. & MTZ-50+Lajta eke \\
\hline 3.Talaj elmunkálása & 1994.03.01. & MTZ-50+fogas \\
\hline 4.Tavaszi N-műtrágyázás & 1993.03.04. & Parcellánként kézzel \\
\hline 5.Vetőágykészítés & 1994.03.04. & MTZ-80+kombinátor \\
\hline 6.Vetés gabonasortávolságra & 1994.03.04. & MTZ-50+Lajta 32 vetőgép \\
\hline 7.Vetés hengerezése & 1994.03.05. & MTZ-50+gyürüshenger \\
\hline 8.Vetés egyenletesen sorol & 1994.03.24. & Az egész kísérletben \\
\hline 9.Bonitálás fejlettségre & 1994.05.09. & Parcellánként 1-5 skálán \\
\hline 10.Mintavétel bokrosodásban & 1994.05.09. & Parcellánként $4-4 \mathrm{fm}=0,5 \mathrm{~m}^{2}$ \\
\hline 11.Permetezés vetésfehérítő ellen & 1994.05.25. & MTZ-50+NOVOR (DIMELRON) \\
\hline 12.Bonitálás vetésfehérítőre & 1994.05.30. & Parcellánként 1-5 skálán \\
\hline 13.Permetezés vetésfehérítő ellen & 1994.05.30. & MTZ+50+MONOR (DIMELRON) \\
\hline 14.Szabadföldi kísérleti bemutató & 1994.06.07. & Országos szakmai részvétel \\
\hline 15.Bonitálás aratás előtt & 1994.07.20. & Parcellánként 1-5 skálán \\
\hline 16.Mintakéve vétele aratáskor & 1994.07.21. & Parcellánként 4-4 fm =0,5 m² \\
\hline 17.Kombájnolás & 1994.07.21. & Parcellánként 7 x 2,1 = 14,7 m² \\
\hline 18.Mintakévék cséplése & 1994.08.18. & Parcellánként feldolgozás \\
\hline
\end{tabular}

Megjegyzés: Bakonyalja fajta elvetve 4-6 cm mélyre 50-60 db/fm, illetve $150 \mathrm{~kg} \cdot \mathrm{ha}^{-}{ }^{1}$ vetőmagnormával

\section{Kísérleti eredmények}

A kísérlet első évében 1988-ban tavaszi árpát termesztettünk lucerna elővetemény után. A N-trágyázás 20-25\%-os szemterméscsökkenést eredményezett az aszályos évben. A Cu-trágyázás hatástalan maradt. A második évben közepes csapadékellátottság mellett kielégítő $6 \mathrm{t} \cdot \mathrm{ha}^{-1}$ körüli őszi búzaszem és szalma tömeget mértünk. A $\mathrm{N}$ és $\mathrm{Cu}$ trágyahatások elmaradtak. A harmadik évben termett öszi árpa szemtömegét a $100 \mathrm{~kg} \cdot \mathrm{ha}^{-1} /$ lév N-adag közel 40\%-kal növelte, míg a Ntúltrágyázás már igazolható, mérsékelt depressziót eredményezett. Csapadékban szegénynek minősült az 1991-es negyedik kísérleti év is. A kukoricában a trágyahatások elmaradtak. A tritikále 1992-ben a $100 \mathrm{~kg} \cdot \mathrm{ha}^{-1}$ /év N-trágyázást meghálálta. Az e feletti $\mathrm{N}$-adagok és a Cu-trágya a terméseket nem befolyásolta. Az aszályos 1993-ban a burgonya terméscsökkenéssel reagált a N-kezelésekre. A Cu és Mo kezelések csak a termés elemösszetételére voltak hatással (KÁDÁR és CSATHÓ 2013, KÁDÁR 2016).

A zab tenyészideje alatt kifejezett volt a csapadékhiány. A talaj tárolt vízkészlete a tenyészidő első felében azonban kielégítette a növény igényét. Bonitálási adataink, illetve a hajtás tömegének mérése szerint bokrosodás végén a kontroll parcellák zöld termését több mint kétszeresére növelte a böséges N- 
adagolás. Depresszió nem jelentkezett. A légszáraz hozam kevésbé látványosan emelkedett, mert a N-bőséggel nagyobb víztartalom járt együtt, illetve a növényi szövetek szárazanyag tartalma drasztikusan csökkent. A fellépő vetésfehérítő kártétele becsléseink szerint a N-böséggel megáldott növényeken megtöbbszöröződött. A szalma tömege aratás idején részben az aszály, részben a vetésfehérítő kártétele miatt mérsékelt maradt és a bokrosodáskori N-hatások is jórészt elenyésztek. Eredményeinket a 3. táblázat foglalja össze.

\section{3. táblázat}

$\mathrm{N}$-szintek hatása a zabra 1994-ben

(Mészlepedékes csernozjom vályogtalaj, Nagyhörcsök, Mezőföld)

\begin{tabular}{|c|c|c|c|c|c|c|c|}
\hline \multirow{2}{*}{$\begin{array}{l}\mathrm{N} \text {-szintek } \\
\mathrm{kg} \cdot \mathrm{ha}^{-1} \cdot \mathrm{év}^{-}\end{array}$} & \multirow{2}{*}{$\begin{array}{l}{ }^{1} \text { Bonitálás } \\
\text { 05.09-én }\end{array}$} & \multirow{2}{*}{$\begin{array}{l}{ }^{2} \text { Bonitálás } \\
\text { 05.30-án }\end{array}$} & \multirow{2}{*}{$\begin{array}{l}{ }^{3} \text { Hajtás* } \\
05.09 \text {-én }\end{array}$} & \multirow{2}{*}{$\begin{array}{l}\text { Lész.anyag } \\
\text { 05.09-én }\end{array}$} & \multicolumn{3}{|c|}{ Aratáskor 07.21-én, $\mathrm{t} \cdot \mathrm{ha}^{-1}$} \\
\hline & & & & & Szalma & Pelyva & Együtt \\
\hline 0 & 1,0 & 1,3 & 6,9 & 18,8 & 3,23 & 0,67 & 3,90 \\
\hline 100 & 3,1 & 2,9 & 11,1 & 15,2 & 3,74 & 0,69 & 4,43 \\
\hline 200 & 4,7 & 4,6 & 1,7 & 14,4 & 3,79 & 0,60 & 4,39 \\
\hline 300 & 4,9 & 4,6 & 12,0 & 14,0 & 3,78 & 0,55 & 4,33 \\
\hline $\mathrm{SzD}_{5 \%}$ & 0,2 & 0,8 & 9 & 0,5 & 0,33 & 0,15 & 0,40 \\
\hline Átlag & 3,4 & 3,4 & 10,4 & 15,6 & 3,64 & 0,63 & 4,27 \\
\hline
\end{tabular}

Bonitálás 05.09 -én $\left(1=\right.$ gyengén, $5=$ jól fejlett állomány); ${ }^{2}$ Bonitál
$10 \%$ alatti, $5=40-50 \%$-os kártétel), ${ }^{3 *}$ Hajtás (légszáraz tömeg g/ $0,5 \mathrm{~m}^{2}$ )

A generatív fejlődési fázisban egyértelművé válik a N-okozta depresszió. Mérséklődik a területegységre eső kalászok száma, szemek száma, az ezerszem és a hektáronkénti szemtermés tömege. Ezzel együtt a szalma/szem, illetve a melléktermés/szemtermés aránya 1-ről a 2-re tágul. Megemlítjük, hogy a pelyva tömege átlagosan $0,63 \mathrm{t} \cdot \mathrm{ha}^{-1}$ mennyiséget tett $\mathrm{ki}$, míg az aratáskori átlagos növénymagasság 77-80 cm volt a kezelésektöl függetlenül. A Cu és a Mo kezelések a korábbi évekhez hasonlóan a termések tömegét igazolhatóan nem befolyásolták. A N-szintek aratáskori terméselemekre gyakorolt hatását a 4. táblázat adatain tanulmányozhatjuk.

$$
\text { 4. táblázat }
$$

N-szintek hatása az aratáskori terméselemekre 1994-ben(Mészlepedékes csernozjom vályogtalaj, Nagyhörcsök, Mezöföld) Megjegyzés: átlagos növénymagasság $77 \mathrm{~cm}$

\begin{tabular}{|l|l|l|l|l|l|l|l|}
\hline N-szintek & Kalász & Szem & 1000 -szem & Szem termés & Szalma & Pelyva & Melléktermés \\
\hline $\mathrm{kg} \cdot$ ha $^{-1} / \mathrm{év}$ & $\begin{array}{l}\mathrm{db} / 0,5 \\
\mathrm{~m}^{2}\end{array}$ & $\begin{array}{l}1000 \\
\mathrm{db} / \mathrm{m}^{2}\end{array}$ & $\mathrm{~g}$ & $\mathrm{t} \cdot \mathrm{ha}^{-1}$ & Szem & Szem & Szem \\
\hline 0 & 225 & 12,5 & 30,1 & 3,75 & 0,86 & 0,18 & 1,04 \\
\hline 100 & 175 & 12,2 & 27,0 & 3,28 & 1,14 & 0,21 & 1,35 \\
\hline 200 & 149 & 9,3 & 27,2 & 2,53 & 1,51 & 0,24 & 1,75 \\
\hline 300 & 140 & 7,8 & 27,4 & 2,14 & 1,77 & 0,26 & 2,03 \\
\hline & & & & & & & \\
\hline SzD & 20 & 1,2 & 1,2 & 0,24 & 0,41 & 0,05 & 0,62 \\
\hline Átlag & 172 & 10,4 & 27,9 & 2,92 & 1,32 & 0,22 & 1,54 \\
\hline
\end{tabular}


A N-trágyázás egyéb elemek felvételét serkentő befolyása látványosan jelentkezik. Bokrosodáskor igazolhatóan nő a $\mathrm{N}, \mathrm{K}, \mathrm{Ca}, \mathrm{P}, \mathrm{S}, \mathrm{Mg}, \mathrm{Na}$ elemek koncentrációja a hajtásban. Legkifejezettebben a Na-é, mely megkétszereződik. Ez alól csak a Ba kivétel, mely feleződik a N-böséggel. Az aratás idején a szalmában mintegy a 3-szorosára emelkedik a $\mathrm{Ni}$, kétszeresére a $\mathrm{N}$ és a $\mathrm{P}$, de erőteljesen nő a $\mathrm{S}$ és $\mathrm{Mg}$ tartalom is. A szalma Na-készlete ugyanakkor esetenként nagyságrenddel megugrik a bokrosodás idején mérthez képest, de a N-bőséggel drasztikusan visszaesik, közel a felére. A mag genetikailag védett, összetétele kevésbé módosul. A szalmához viszonyítva dúsul $\mathrm{N}, \mathrm{P}, \mathrm{Ni}$ elemekben, illetve elszegényedik $\mathrm{K}, \mathrm{Ca}$, $\mathrm{Na}$, Ba elemekben. A mag átlagos $\mathrm{S}$ és $\mathrm{Mg}$ készlete kiegyenlítettnek tünik a vegetatív és a generatív szervekben (5. táblázat).

\section{5. táblázat}

N-szintek hatása a zab elemtartalmára 1994-ben (Mészlepedékes csernozjom vályogtalaj, Nagyhörcsök, Mezőföld)

\begin{tabular}{|c|c|c|c|c|c|c|c|c|}
\hline N-szint & \multicolumn{6}{|c|}{$\%$} & \multicolumn{2}{|c|}{$\mathrm{mg} \cdot \mathrm{kg}^{-1}$} \\
\hline $\mathrm{kg} \cdot \mathrm{ha}^{-1} \cdot \mathrm{év}^{-1}$ & $\mathrm{~N}$ & $\mathrm{~K}$ & $\mathrm{Ca}$ & $\mathrm{P}$ & $\mathrm{S}$ & $\mathrm{Mg}$ & $\mathrm{Na}$ & $\mathrm{Ni}$ \\
\hline \multicolumn{9}{|c|}{ Bokrosodáskori hajtás 05.09-én } \\
\hline 0 & 4,28 & 3,89 & 0,68 & 0,40 & 0,32 & 0,14 & 111 & 2,8 \\
\hline 100 & 5,28 & 4,40 & 0,73 & 0,40 & 0,36 & 0,15 & 131 & 2,1 \\
\hline 200 & 5,30 & 4,71 & 0,71 & 0,43 & 0,43 & 0,18 & 205 & 2,3 \\
\hline 300 & 5,67 & 4,90 & 0,71 & 0,45 & 0,45 & 0,19 & 224 & 2,8 \\
\hline $\mathrm{SzD}_{5 \%}$ & 0,34 & 0,33 & 0,04 & 0,02 & 0,03 & 0,03 & 48 & 0,8 \\
\hline Átlag & 5,10 & 4,48 & 0,70 & 0,42 & 0,39 & 0,16 & 168 & 2,2 \\
\hline \multicolumn{9}{|c|}{ Szalma aratáskor 07.21-én } \\
\hline 0 & 0,39 & 1,59 & 0,43 & 0,07 & 0,13 & 0,13 & 1898 & 0,3 \\
\hline 100 & 0,60 & 1,72 & 0,46 & 0,08 & 0,15 & 0,14 & 1383 & 0,5 \\
\hline 200 & 0,76 & 1,82 & 0,53 & 0,12 & 0,20 & 0,17 & 1179 & 0,8 \\
\hline 300 & 0,88 & 1,90 & 0,64 & 0,13 & 0,22 & 0,18 & 1005 & 1,0 \\
\hline $\mathrm{SzD}_{5 \%}$ & 0,88 & 0,13 & 0,07 & 0,02 & 0,02 & 0,02 & 485 & 0,3 \\
\hline Átlag & 0,66 & 1,76 & 0,52 & 0,10 & 0,17 & 0,15 & 1366 & 0,6 \\
\hline \multicolumn{9}{|c|}{ Szem aratáskor 07.21-én } \\
\hline 0 & 1,90 & 0,47 & 0,10 & 0,40 & 0,18 & 0,13 & 80 & 2,8 \\
\hline 100 & 2,10 & 0,48 & 0,10 & 0,40 & 0,19 & 0,14 & 75 & 3,6 \\
\hline 200 & 2,17 & 0,49 & 0,11 & 0,44 & 0,20 & 0,15 & 69 & 4,6 \\
\hline 300 & 2,25 & 0,50 & 0,13 & 0,46 & 0,21 & 0,16 & 68 & 5,3 \\
\hline $\mathrm{SzD}_{5 \%}$ & 0,14 & 0,05 & 0,01 & 0,03 & 0,01 & 0,01 & 11 & 0,4 \\
\hline Átlag & 2,10 & 0,49 & 0,11 & 0,42 & 0,19 & 0,14 & 73 & 4,0 \\
\hline
\end{tabular}


A növény tápláltsági állapotát értékelve levéldiagnosztikai szempontból korábban megállapítottuk, hogy a zab kielégítően ellátott NPK elemekkel, amennyiben a bokrosodáskori földfeletti hajtása szárazanyagra számítva 4-5\% N és $\mathrm{K}, 0,4-0,5 \% \mathrm{P}$ elemet tartalmaz. Az optimális N/P és $\mathrm{K} / \mathrm{P}$ aránya tehát 10 körüli (KÁDÁR és LÁSZTITY 1997B). BERGMANN (1992) az alábbi tágabb optimumokat közli a zab bokrosodáskori összetételére: N 3-5\%, K 4-6\%, P 0,3-0,6\%; Ca 0,51,0\%; Mg 0,2-0,3\%; Mn 40-100, Zn 25-70, B és Cu 6-12, Mo 0,15-0,40 mg. $\mathrm{kg}^{-1}$. Az 5. táblázat adataiból megállapítható, hogy az állomány a N, P, K, Ca, valamint a $\mathrm{S}$ és Mg elemekkel egyaránt kielégítően ellátott volt.

\section{6. táblázat}

N-szintek hatása a zab B, Ba és Al tartalmára 1994-ben, $\mathrm{mg} \cdot \mathrm{kg}^{-1}$

(Mészlepedékes csernozjom vályogtalaj, Nagyhörcsök, Mezőföld)

\begin{tabular}{|c|c|c|c|c|c|c|c|}
\hline $\mathrm{N}$-szintek & \multicolumn{3}{|c|}{ Hajtás 05.09-én } & \multicolumn{2}{|c|}{ Szalma 07.21-én } & \multicolumn{2}{|c|}{ Szem 07.21-én } \\
\hline $\mathrm{kg} \cdot \mathrm{ha}^{-1} \mathrm{év}^{-1}$ & $\mathrm{Al}$ & $\mathrm{Ba}$ & B & $\mathrm{Al}$ & $\mathrm{Ba}$ & $\mathrm{Ba}$ & B \\
\hline 0 & 51 & 3,1 & 3,9 & 44 & 14 & 1,8 & 1,2 \\
\hline 100 & 43 & 2,2 & 4,2 & 58 & 10 & 1,4 & 1,1 \\
\hline 200 & 35 & 1,9 & 4,7 & 60 & 8 & 1,3 & 1,0 \\
\hline 300 & 39 & 1,3 & 4,8 & 66 & 7 & 1,1 & 1,0 \\
\hline $\mathrm{S}_{7} \mathrm{D}_{-}$ & 0 & 06 & 04 & 0 & 2 & ? & 0 \\
\hline Átlag & 42 & 21 & 44 & 57 & 10 & 14 & 11 \\
\hline Aliag & 42 & 2,1 & 4,4 & Ji & 10 & 1,4 & 1,1 \\
\hline
\end{tabular}

A 6. táblázat eredményei alapján arra következtethetünk, hogy a N-böséggel az Al és Ba koncentrációja hígult a nagyobb tömegủ hajtásban, míg a B-felvétel javult. Az aratáskori szalmában nőtt az Al tartalom a Ba-tartalom egyidejü csökkenése mellett. Annak ellenére, hogy a zab szemtermése aratáskor drasztikusan visszaesett, a Ba és B elem tartalma mérséklődött a trágyázatlan kontrollhoz képest.

A $\mathrm{Cu}$ beépülését mind a $\mathrm{N}$, mind a $\mathrm{Cu}$ kínálata serkenti. Bokrosodáskor a poziív kölcsönhatások eredőjeként a kontrollon mért $4 \mathrm{mg} \cdot \mathrm{kg}^{-1}$ közel a 3-szorosára ugrik. Érdekes megemlíteni, hogy a N-trágyázás kifejezettebben növeli a $\mathrm{Cu}$ akkumulációját, mint a Cu-trágya. A szalma összetételében is a N-hatások dominálnak. A szem esetében a hatások kiegyensúlyozottnak tủnnek: BERGMANN (1992) szerint a Cu-tartalom optimuma a hajtásban $6-12 \mathrm{mg} \cdot \mathrm{kg}^{-1}$ tartományban van, tehát a kiváltott $\mathrm{Cu}$-koncentráció emelkedése előnyös lehet (7. táblázat). 


\section{7. táblázat}

N x Cu szintek hatása a zab Cu-tartalmára 1994-ben, $\mathrm{mg} \cdot \mathrm{kg}^{-1}$ (Mészlepedékes csernozjom vályogtalaj, Nagyhörcsök, Mezőföld)

\begin{tabular}{|c|c|c|c|c|c|c|}
\hline \multirow{2}{*}{$\begin{array}{c}\text { Cu-szintek } \\
\mathrm{kg} \cdot \mathrm{ha}^{-1}\end{array}$} & \multicolumn{4}{|c|}{$\mathrm{N}$-szintek, $\mathrm{N} \mathrm{kg} \cdot \mathrm{ha}^{-1} \mathrm{év}^{-1}$} & \multirow[b]{2}{*}{$\mathrm{SzD}_{5 \%}$} & \multirow[b]{2}{*}{ Átlag } \\
\hline & 0 & 100 & 200 & 300 & & \\
\hline \multicolumn{7}{|c|}{ Hajtás bokrosodásban 05.09-én } \\
\hline 0 & 4,0 & $\begin{array}{r}6 \\
, 9 \\
\end{array}$ & 9,2 & 8,5 & & 7,2 \\
\hline 50 & 6,3 & $\begin{array}{r}6 \\
9 \\
\end{array}$ & 11,0 & 12,7 & 3,7 & 9,2 \\
\hline 100 & 6,6 & $\begin{array}{r}9 \\
9 \\
9\end{array}$ & 9,5 & 13,9 & & 10,0 \\
\hline $\mathrm{SzD}_{5 \%}$ & \multicolumn{4}{|c|}{1,8} & & 1,3 \\
\hline Átlag & 5,6 & $\begin{array}{r}7 \\
, 9 \\
\end{array}$ & 9,9 & 11,7 & 2,0 & 8,8 \\
\hline \multicolumn{7}{|c|}{ Szalma aratáskor 07.21-én } \\
\hline 0 & 2,2 & 2,8 & 3,3 & 3,8 & & 3,0 \\
\hline 50 & 2,8 & 3,3 & 4,2 & 5,1 & 1,2 & 3,8 \\
\hline 100 & 2,7 & 3,3 & 4,0 & 4,6 & & 3,7 \\
\hline $\mathrm{SzD}_{5 \%}$ & \multicolumn{4}{|c|}{0,9} & & 0,6 \\
\hline Átlag & 2,6 & 3,1 & 3,8 & 4,5 & 0,7 & 3,5 \\
\hline \multicolumn{7}{|c|}{ Szem aratáskor 07.21-én } \\
\hline 0 & 3,8 & 4,1 & 3,7 & 3,9 & & 3,9 \\
\hline 50 & 3,8 & 4,5 & 4,8 & 5,0 & 0,5 & 4,5 \\
\hline 100 & 4,4 & 4,5 & 4,8 & 5,2 & & 4,7 \\
\hline $\mathrm{SzD}_{5 \%}$ & \multicolumn{4}{|c|}{0,5} & & 0,3 \\
\hline Átlag & 4,0 & 4,4 & 4,4 & 4,7 & 0,3 & 4,4 \\
\hline
\end{tabular}

A N némileg növelte a növényi szervek Mo-készletét szennyezetlen talajon. A két évvel korábbi egyszeri adag $48 \mathrm{~kg} \cdot \mathrm{ha}^{-1}$ Mo-adag nyomán az eredeti Mo-tartalom a vegetatív részekben két nagyságrenddel dúsult. De a szemtermésben is megnégyszereződött (8. táblázat). Korábbi, e talajon végzett vizsgálataink igazolták, hogy a Mo a Se elemhekez hasonlóan hiperakkumulációra képes és nagyságrendekkel dúsulhat (KÁDÁR 1995). A Mo-nel trágyázott talajon fejlődött zab takarmányozási célokra és humán fogyasztásra egyaránt alkalmatlanná vált. A vegetatív növényi részek molibdenozist okozhatnak az állatban. Közvetve Cu-hiány is indukálódik, amennyiben a normális 10 körüli, $\mathrm{Cu} / \mathrm{Mo}$ aránya drasztikusan megváltozik. 


\section{8. táblázat}

N x Mo szintek hatása a zab Mo-tartalmára 1994-ben, $\mathrm{mg} \cdot \mathrm{kg}^{-1}$ (Mészlepedékes csernozjom vályogtalaj, Nagyhörcsök, Mezőföld)

\begin{tabular}{|c|c|c|c|c|c|c|}
\hline Mo- & \multicolumn{4}{|c|}{$\mathrm{N}$-szintek kg.ha- ${ }^{-1} \mathrm{év}^{-1}$} & & \multirow[b]{2}{*}{ Átlag } \\
\hline $\mathrm{kg} \cdot \mathrm{ha}^{-1}$ & 0 & 100 & 200 & 300 & $\mathrm{SzD}_{5}$ & \\
\hline \multicolumn{7}{|c|}{ Hajtás bokrosodásban 05.09-én } \\
\hline 0 & 2,5 & 4,4 & 5,8 & 5,1 & & 4,5 \\
\hline 67 & 89,2 & 94,5 & 95,8 & 92,3 & 3,6 & 92,9 \\
\hline $\mathrm{SzD}_{5 \%}$ & \multicolumn{4}{|c|}{54,4} & & 33,2 \\
\hline Átlag & 45,9 & 49,4 & 50,8 & 48,7 & 2,2 & 48,7 \\
\hline \multicolumn{7}{|c|}{ Szalma aratásban 07.21-én } \\
\hline 0 & 0,3 & 0,4 & 0,5 & 0,9 & & 0,5 \\
\hline 67 & 27,7 & 33,4 & 47,8 & 41,7 & 12,4 & 37,6 \\
\hline $\mathrm{SzD}_{5 \%}$ & \multicolumn{4}{|c|}{24,6} & & 14,0 \\
\hline Átlag & 14,0 & 16,9 & 24,2 & 21,3 & 9,2 & 19,1 \\
\hline \multicolumn{7}{|c|}{ Szem aratásban 07.21-én } \\
\hline 0 & 2,0 & 2,3 & 2,7 & 3,2 & & 2,5 \\
\hline 67 & $\begin{array}{r}12, \\
1\end{array}$ & 10,8 & 12,3 & 11,4 & 1,2 & 11,7 \\
\hline $\mathrm{SzD}_{5 \%}$ & \multicolumn{4}{|c|}{4,2} & & 2,5 \\
\hline Átlag & 7,0 & 6,6 & 7,5 & 7,3 & 0,8 & 7,1 \\
\hline
\end{tabular}

A 9. táblázat áttekintést ad a légszáraz zab átlagos összetételről a vizsgált 24 elemre növényi részenként. Látható, hogy a fiatal hajtás a leggazdagabb N, K, Ca, $\mathrm{S}, \mathrm{Mn}, \mathrm{Fe}, \mathrm{B}, \mathrm{Cu}$, Pb elemekben. Szalmában a $\mathrm{Na}, \mathrm{Al}, \mathrm{Sr}, \mathrm{Ba}$, míg a szemtermésben a $\mathrm{Zn}, \mathrm{Mo}, \mathrm{Ni}, \mathrm{Se}, \mathrm{Cr}$ elemek dúsultak. Ami az aratáskori terméssel távozó elemek mennyiségeit illeti megállapítható, hogy a szemtermésbe épült a felvett $\mathrm{N}, \mathrm{P}, \mathrm{Zn}$, Mo, Ni, Se, Cr nagyobb része, mely kombájn aratáskor távozik a tábláról. Amennyiben a szalmát beszántjuk, a K, Ca, Mg, S, Na, Fe, Mn, Al, Sr, Ba, B, Pb elemek döntően visszakerülnek a talajba. Az 1 t szem + a hozzátartozó melléktermés úgynevezett fajlagos elemigénye $30 \mathrm{~kg} \mathrm{~N}$ és K, 8-10 kg Ca, 5-6 kg P (11-13 kg $\mathrm{P}_{2} \mathrm{O}_{5}$ ), 4-5 kg S és 3-4 kg Mg mennyiségnek adódott a kísérlet átlagában. Adataink felhasználhatók a szaktanácsadásban a tervezett termés elemigényének becslésekor. 
9. táblázat

A zab átlagos összetétele és elemfelvétele 1994-ben (Mészlepedékes csernozjom vályogtalaj, Nagyhörcsök, Mezőföld)

\begin{tabular}{|c|c|c|c|c|c|c|c|c|c|}
\hline Elem & Mérték- & Hajtás & Szalma & Szem & Mérték- & Szalma & Szem & Együtt & Fajlagos \\
\hline jele & egység & $\begin{array}{l}05.09- \\
\text { én }\end{array}$ & \multicolumn{2}{|c|}{ 07.21-én } & egység & \multicolumn{4}{|c|}{ 07.21-én aratáskor } \\
\hline $\mathrm{N}$ & $\%$ & 5,10 & 0,66 & 2,10 & $\mathrm{~kg} \cdot \mathrm{ha}^{-1}$ & 28,2 & 61,3 & 89,5 & 31 \\
\hline $\mathrm{K}$ & $\%$ & 4,48 & 1,76 & 0,49 & $\mathrm{~kg} \cdot \mathrm{ha}^{-1}$ & 75,2 & 14,3 & 89,5 & 31 \\
\hline $\mathrm{Ca}$ & $\%$ & 0,70 & 0,64 & 0,11 & $\mathrm{~kg} \cdot \mathrm{ha}^{-1}$ & 27,3 & 3,2 & 30,5 & 10 \\
\hline $\mathrm{P}$ & $\%$ & 0,42 & 0,10 & 0,42 & $\mathrm{~kg} \cdot \mathrm{ha}^{-1}$ & 4,3 & 12,3 & 16,6 & 6 \\
\hline $\mathrm{S}$ & $\%$ & 0,39 & 0,17 & 0,19 & $\mathrm{~kg} \cdot \mathrm{ha}^{-1}$ & 7,3 & 5,5 & 12,8 & 4 \\
\hline $\mathrm{Mg}$ & $\%$ & 0,16 & 0,15 & 0,15 & $\mathrm{~kg} \cdot \mathrm{ha}^{-1}$ & 6,4 & 4,4 & 10,8 & 4 \\
\hline $\mathrm{Mn}$ & $\mathrm{mg} \cdot \mathrm{kg}^{-1}$ & 189 & 105 & 61 & $g \cdot h a^{-1}$ & 448 & 178 & 626 & 214 \\
\hline $\mathrm{Fe}$ & $\mathrm{mg} \cdot \mathrm{kg}^{-1}$ & 150 & 118 & 92 & $\mathrm{~g} \cdot \mathrm{ha}^{-1}$ & 504 & 269 & 773 & 265 \\
\hline $\mathrm{Na}$ & $\mathrm{mg} \cdot \mathrm{kg}^{-1}$ & 168 & 1366 & 73 & $\mathrm{~g} \cdot \mathrm{ha}^{-1}$ & 5833 & 213 & 6046 & 2070 \\
\hline $\mathrm{Al}$ & $\mathrm{mg} \cdot \mathrm{kg}^{-1}$ & 42 & 57 & 9 & $\mathrm{~g} \cdot \mathrm{ha}^{-1}$ & 243 & 26 & 269 & 92 \\
\hline $\mathrm{Sr}$ & $\mathrm{mg} \cdot \mathrm{kg}^{-1}$ & 24 & 24 & 4 & $\mathrm{~g} \cdot \mathrm{ha}^{-1}$ & 102 & 12 & 114 & 39 \\
\hline $\mathrm{Ba}$ & $\mathrm{mg} \cdot \mathrm{kg}^{-1}$ & 2 & 10 & 1 & $\mathrm{~g} \cdot \mathrm{ha}^{-1}$ & 43 & 3 & 46 & 16 \\
\hline $\mathrm{Zn}$ & $\mathrm{mg} \cdot \mathrm{kg}^{-1}$ & 10 & 5 & 19 & $g \cdot h^{-1}$ & 21 & 55 & 76 & 26 \\
\hline $\mathrm{B}$ & $\mathrm{mg} \cdot \mathrm{kg}^{-1}$ & 4,4 & 3,4 & 1,1 & $g \cdot h^{-1}$ & 14,5 & 3,2 & 17,7 & 6 \\
\hline $\mathrm{Cu}$ & $\mathrm{mg} \cdot \mathrm{kg}^{-1}$ & 7,2 & 3,0 & 4,4 & g.ha ${ }^{-1}$ & 12,8 & 12,8 & 25,6 & 9 \\
\hline Mo & $\mathrm{mg} \cdot \mathrm{kg}^{-1}$ & 4,5 & 0,5 & 2,5 & $\mathrm{~g} \cdot \mathrm{ha}^{-1}$ & 2,1 & 7,3 & 9,4 & 3 \\
\hline $\mathrm{Ni}$ & $\mathrm{mg} \cdot \mathrm{kg}^{-1}$ & 2,2 & 0,6 & 4,0 & $g \cdot h^{-1}$ & 2,6 & 11,7 & 14,3 & 5 \\
\hline $\mathrm{Se}$ & $\mathrm{mg} \cdot \mathrm{kg}^{-1}$ & 0,8 & 0,5 & 0,8 & g.ha ${ }^{-1}$ & 2,1 & 2,3 & 4,4 & 2 \\
\hline $\mathrm{Pb}$ & $\mathrm{mg} \cdot \mathrm{kg}^{-1}$ & 0,6 & 0,5 & 0,2 & $\mathrm{~g} \cdot \mathrm{ha}^{-1}$ & 2,1 & 0,6 & 2,7 & 1 \\
\hline $\mathrm{Cr}$ & $\mathrm{mg} \cdot \mathrm{kg}^{-1}$ & 0,2 & $<0,1$ & 0,4 & $\mathrm{~g} \cdot \mathrm{ha}^{-1}$ & $<1,0$ & 1,0 & 1,0 & $<1$ \\
\hline $\mathrm{Cd}$ & $\mathrm{mg} \cdot \mathrm{kg}^{-1}$ & $<0,1$ & $<0,1$ & $<0,1$ & $g \cdot h^{-1}$ & $<1,0$ & $<1,0$ & $<1,0$ & $<1$ \\
\hline $\mathrm{Co}$ & $\mathrm{mg} \cdot \mathrm{kg}^{-1}$ & $<0,1$ & $<0,1$ & $<0,1$ & $\mathrm{~g} \cdot \mathrm{ha}^{-1}$ & $<1,0$ & $<1,0$ & $<1,0$ & $<1$ \\
\hline
\end{tabular}

Megjegyzés: szalma+pelyva 4,27 th ha ${ }^{-1}$, szem 2,92 t $\cdot \mathrm{ha}^{-1}$ tömeggel számolva

Figyelembe kell venni azonban, hogy a N-túltrágyázás és az aszály okozta kicsi termésekben a tápelemek betöményednek. Mindez a fajlagos elemtartalmakat torzítja, növeli. Különösen kiugrónak minősülhetnek a $36 \mathrm{~kg} \mathrm{~K} 2 \mathrm{O}$, illetve föként a 11-14 kg CaO és 4-6 kg MgO emelkedett értékei. Utóbbihoz a meszes, $\mathrm{Ca}$ és $\mathrm{Mg}$ elemekben gazdag termőhely elemkínálata is hozzájárul. Ismert az is, hogy a Ca méregtelenítő, sejtfalat záró funkciót is betölt. Mérgezés esetén a Ca (részben a Mg) extrém módon feldúsulhat a sejtekben és az érintett szövetekben. Ebböl adódik, hogy a hazai szaktanácsadásban ajánlott fajlagos $\mathrm{CaO}$ és $\mathrm{MgO}$ tartalmak kétszeresét mértük kísérletünkben. 


\section{Összefoglalás}

Mészlepedékes csernozjom vályogtalajon beállított szabadföldi kísérletben vizsgáltuk a N, Cu és Mo elemek közötti kölcsönhatásokat 1994-ben zab növénnyel. Termőhely talaja a szántott rétegben 3\% humuszt, $5 \%$ körüli $\mathrm{CaCO}_{3}$-ot és 20\% körüli agyagot tartalmazott. Talajelemzések alapján a terület jó $\mathrm{Ca}, \mathrm{Mg}, \mathrm{K}$, $\mathrm{Mn}$, kielégítő $\mathrm{Cu}$, valamint gyenge-közepes $\mathrm{P}$ és $\mathrm{Zn}$ ellátottságú volt. A talajvíz 13$15 \mathrm{~m}$ mélyen található, a terület aszályérzékeny. A kísérletet $4 \mathrm{~N}$ x $3 \mathrm{Cu}=12$ kezelés x 3 ismétlés $=36$ parcellával állítottuk be osztott parcellás (split-plot) elrendezéssel.

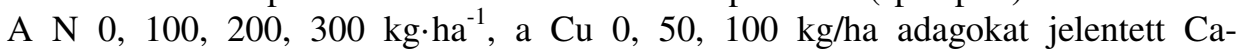
ammóniumnitrát, illetve $\mathrm{CuSO}_{4}$ formájában. A kísérlet 5. évében a $15 \mathrm{~m}$ hosszú parcellákat megfeleztük és $1 \mathrm{~m}$-es úttal elválasztottuk. A kísérlet sávos split-plot elrendezésüvé vált $4 \mathrm{Nx} 3 \mathrm{Cux} 2 \mathrm{Mo}=24$ kezelés $\times 3$ ismétlés $=72$ parcellával. A 48 $\mathrm{kg} \cdot h a^{-1}$ Mo-t $\left(\mathrm{NH}_{4}\right)_{6} \mathrm{Mo}_{7} \mathrm{O}_{24} \cdot 4 \mathrm{H}_{2} \mathrm{O}$ formában alkalmaztuk. Főbb eredmények:

- Az aszályos évben mindössze $137 \mathrm{~mm}$ eső esett a zab 140 napos tenyészideje alatt. A N-trágyázásra a kontrollon mért 3,8 th ha ${ }^{-1}$ szemtermés 2,1 $\mathrm{t} \cdot$ ha ${ }^{1}$-ra zuhant. A Cu és a Mo kezelések a terméstömeget nem befolyásolták, hasonlóan a korábbi évekhez.

- A N-bőséggel emelkedett a N, Ca, K, P, S, Mg, Ni koncentrációja a bokrosodáskori hajtásban, aratáskori szalmában és szemben egyaránt, míg a $\mathrm{Na}$ és Ba mennyisége visszaesett aratás idején.

- A Cu beépülését mind a $\mathrm{Cu}$, mind a $\mathrm{N}$ kínálata serkentette. A fiatal hajtás Cu-tartalma a pozitív $\mathrm{NxCu}$ kölcsönhatás nyomán megháromszorozódott. A Ntrágyázás kifejezettebben növelte a Cu-tartalmat, mint a Cu-trágya.

- A két évvel korábban adott $48 \mathrm{~kg} \cdot \mathrm{ha}^{-1}$ Mo-adag nyomán a zab vegetatív részeinek Mo-koncentrációja két nagyságrenddel dúsult és a magban is többszörösére nött. A termés állati fogyasztásra alkalmatlanná vált.

- Az $1 \mathrm{t}$ szem + a hozzátartozó melléktermés fajlagos elemtartalma $30 \mathrm{~kg} \mathrm{~N}$, $36 \mathrm{~kg} \mathrm{~K}_{2} \mathrm{O}, 11-13 \mathrm{~kg} \mathrm{P}_{2} \mathrm{O}_{5}, 11-14 \mathrm{~kg} \mathrm{CaO}, 4-6 \mathrm{~kg} \mathrm{MgO}$ mennyiségnek adódott. A N túltrágyázás okozta depresszió (kis termések) miatt az elemtartalom megnőtt (betöményedett) a növényi szövetekben. Az extrém nagy $\mathrm{CaO}$ és $\mathrm{MgO}$ fajlagos értékek létrejöttéhez a meszes, $\mathrm{Ca}$ és $\mathrm{Mg}$ elemekben gazdag termöhely is hozzájárulhatott.

Kulcsszavak: Nitrogén Réz Molibdén kölcsönhatások, tartamkísérlet, zab, csernozjom talaj 


\section{Irodalom}

ANTAL J. 2000. Növénytermesztők zsebkönyve. Falugazdász Könyvek. Mezőgazd. Kiadó. Budapest.

BARANYAI F., FEKETE A. \& KovÁcs I. 1987. A magyarországi talaj tápanyagvizsgálatok eredményei. Mezőgazdasági Kiadó. Budapest.

BergmanN, W. 1992. Nutritional Disorders of Plants. G. Fischer Verlag. Jena, Stuttgart, New York.

BUZÁS I. et al. (Szerk:1979): Mütrágyázási irányelvek és üzemi számítási módszer. MÉM Növényvédelmi és Agrokémiai Központ. Budapest.

CSERHÁTI S. 1901. Általános és különleges növénytermelés. II. Magyar-Óvár. Czéh Sándor-féle Könyvnyomda.

EgNÉR, H. , RIEHM, H. \& DOMINGO, W.R. 1960. Untersuchungen über die chemische Bodenanalyse als Grundlage für die Beurteilung des Nährstoffzustandes der Böden. II. K-Lantbr. Högsk. Ann. 26:199-215.

GRÁBNER E. 1948. Szántóföldi növénytermesztés. Pátria Rt. Budapest.

ISO 11261. 1995. Soil Quality Determination of total nitrogen. Modifid Kjeldahl method.

JAKUSKIN, I.V. 1947. Rasztenievodsztvo. Szel'hozgiz. Moszkva.

JolÁNKAI M. 2005. 8. Fejezet. Zab. 277-283. In: A növénytermesztés alapjai. Szerk.: ANTAL J. Gabonafélék. Mezőgazda Kiadó. Budapest.

KÁDÁR I. 1995. A talaj-növény-állat-ember tápláléklánc szennyeződése kémiai elemekkel Magyarországon. KTM - MTA TAKI. Budapest.

KÁDÁR I. 2016. A NxCuxMo kezelések hatása a tiritikálera. Agrokémia és Talajtan. Megjelenés alatt.

KÁDÁR I. \& CsATHó P. 2013. A N-Cu kölcsönhatások szabadföldi tavaszi árpa kísérletben. Agrokémia és Talajtan. 62(2): 345-358.

KÁDÁR I. \& LÁSZTITY B. 1997a. A zab szárazanyagfelhasználásának és tápelemtartalmának változása a tenyészidő folyamán. Növénytermelés. 46(3): 267-274.

KÁDÁR I. \& LÁszTiTy B. 1997b. A zab tápelemfelvétele a tenyészidő folyamán. Növénytermelés. 46(5): 529-538.

KATALÜMOV, M.V. (1960): Szpravocsnik po Mineral'nüm Udobrenijam. Gosz. Izd. Sz/h Literaturü. Moszkva.

KJELDAHL, J. (1891): Neue Methode zur Bestimmung des Stickstoffs in organischen Körpern. Zeitschr. f. analyt. Chemie. 22:366-382.

LAKANEN, E., ERVIÖ, R. 1971. A comparison of eight extractants for the determination of plant available microelements in soils. Acta Agr. Fenn. 123:223-232.

LÁNG G. 1976. Szántóföldi növénytermesztés. Mezőgazdasági Kiadó. Budapest.

MENGEL K. 1976. A növény táplálkozása és anyagcseréje. Mezőgazdasági Kiadó. Budapest.

MÉM NAK. 1978. A TVG tápanyagvizsgáló laboratórium módszerfüzete. MÉM Növényvédelmi és Agrokémiai Központ. Budapest. 
Mitrofanov, A.Sz. \& Mitrofanova, K.Sz. 1970. A zab. Mezőgazdasági Kiadó. Budapest.

MuRAKÖZI T. (Szerk.: 1958). Mezőgazdasági Lexikon. L-Z. Mezőgazdasági Kiadó. Budapest.

PRIMOST, E. 1965. Hafer (Avena sativa L.). In: Handbuch der Pflanzenernährung und Düngung. Springer Verlag. Wien.

PrJanisnYikOV, D. N. 1931. Csasztnoe Zemledelie. Rasztenija Polevoj Kulturü. Szel'hozgiz. Moszkva- Leningrád.

SCHMIDT, D. R. 1961. Dry matter and nitrogen content of oat harvested at various stages. Agron. J. 53: 8-10.

Radics L. (Szerk.: 2003). Szántóföldi növénytermesztés. Szaktudás Kiadó Ház. Budapest.

TYURIN, I.V. 1937. Organicseszkoe vesesesztvo pocsvï. Szel'hozgiz. Moszkva 


\title{
Effect of nitrogen, copper and molybdenum treatments on oat (Avena sativa L.)
}

\author{
I. KÁDÁR \\ Institute for Soil Sciences and Agricultural Chemistry of the Hungarian Academy of \\ Sciences, Budapest
}

\section{Summary}

Interactions between the elements $\mathrm{N}, \mathrm{Cu}$ and Mo were studied in oat in 1994 in a field experiment set up on chernozem loam soil with lime deposits. The ploughed layer of the soil contained $3 \%$ humus, around $5 \% \mathrm{CaCO}_{3}$ and around $20 \%$ clay. Soil analysis showed that the area was well supplied with $\mathrm{Ca}, \mathrm{Mg}, \mathrm{K}$ and $\mathrm{Mn}$ had satisfactory $\mathrm{Cu}$ content, but was only poorly or moderately supplied with $\mathrm{P}$ and $\mathrm{Zn}$. The groundwater depth was $13-15 \mathrm{~m}$ and the area was prone to drought. The experiment was originally set up in a split-plot design with $4 \mathrm{~N} \times 3 \mathrm{Cu}=12$ treatments in three replications, giving a total of 36 plots. The $\mathrm{N}$ rates, applied as calcium ammonium nitrate, were $0,100,200$ and $300 \mathrm{~kg} \cdot \mathrm{ha}^{-1}$ and the $\mathrm{Cu}$ rates, in the form of $\mathrm{CuSO}_{4}$, were 0,50 and $100 \mathrm{~kg} \cdot \mathrm{ha}{ }^{-1}$. In the $5^{\text {th }}$ year of the experiment the $15 \mathrm{~m}$ long plots were halved and the two half-plots were separated by a $1 \mathrm{~m}$ path. The experiment thus became a strip-split-plot design, consisting of $4 \mathrm{~N} \times 3 \mathrm{Cu} \times 2 \mathrm{Mo}=$ 24 treatments in three replications, giving a total of 72 plots. The $48 \mathrm{~kg} \cdot \mathrm{ha}^{-1} \mathrm{Mo}$ was applied in the form of $\left(\mathrm{NH}_{4}\right)_{6} \mathrm{Mo}_{7} \mathrm{O}_{24} \cdot 4 \mathrm{H}_{2} \mathrm{O}$. The main results were as follows:

In the droughty year the rainfall sum was only $137 \mathrm{~mm}$ during the 140-day growing season of oat. The grain yield decreased from $3.8 \mathrm{t} \cdot \mathrm{ha}^{-1}$ on the control plot to $2.1 \mathrm{t} \cdot \mathrm{ha}^{-1}$ in response to $\mathrm{N}$ fertilization. As in previous years, $\mathrm{Cu}$ and $\mathrm{Mo}$ fertilization had no effect on the yield.

Plentiful $\mathrm{N}$ supplies led to a rise in the concentration of the elements $\mathrm{N}, \mathrm{Ca}, \mathrm{K}$, $\mathrm{P}, \mathrm{S}, \mathrm{Mg}$ and $\mathrm{Ni}$ in the stem at tillering and in the straw and grain at harvest, whereas the $\mathrm{Na}$ and $\mathrm{Ba}$ contents declined up to harvest.

$\mathrm{Cu}$ uptake was enhanced by both $\mathrm{Cu}$ and $\mathrm{N}$ supplies. Due to the positive $\mathrm{N} \times \mathrm{Cu}$ interaction, the $\mathrm{Cu}$ content of the young shoots was tripled. $\mathrm{N}$ fertilization caused a much greater increase in $\mathrm{Cu}$ content than $\mathrm{Cu}$ fertilization.

The Mo concentration was two orders of magnitude higher in the vegetative parts of oat and was also many times greater in the grain in response to the application of $48 \mathrm{~kg} \cdot \mathrm{ha}^{-1}$ Mo two years earlier. The yield became unfit for animal consumption.

The specific nutrient content of $1 \mathrm{t}$ grain yield + associated by-products averaged $30 \mathrm{~kg} \mathrm{~N}, 36 \mathrm{~kg} \mathrm{~K} 2 \mathrm{O}, 11-13 \mathrm{~kg} \mathrm{P}_{2} \mathrm{O}_{5}, 11-14 \mathrm{~kg} \mathrm{CaO}$ and 4-6 kg MgO. Due to the yield depression caused by excessive $\mathrm{N}$ fertilization, the elements became highly concentrated in the plant tissues. The calcareous habitat, rich in $\mathrm{Ca}$ 
and $\mathrm{Mg}$, could also have contributed to the extremely high specific values of $\mathrm{CaO}$ and $\mathrm{MgO}$.

Table 1. Crop sequence in the $\mathrm{N} \times \mathrm{Cu}$ long-term experiment between 1988 and 2002 (chernozem loam soil with lime deposits, Nagyhörcsök, Hungary).

Table 2. Agronomic measures and observations in the oat experiment in 1994 (chernozem loam soil with lime deposits, Nagyhörcsök, Hungary). Note: Cultivar Bakonyalja sown at a depth of 4-6 cm with a seed norm of 50-60 seeds $/ \mathrm{m}$ or 150 $\mathrm{kg} \mathrm{ha}^{-1}$.

Table 3. Effect of $\mathrm{N}$ levels on oat in 1994 (chernozem loam soil with lime deposits, Nagyhörcsök, Hungary). ${ }^{1}$ Scoring on 9 May $(1=$ poorly, $5=$ well/developed stand); ${ }^{2}$ scoring on 30 May ( $1=$ below $10 \%, 5=40-50 \%$ damage); ${ }^{3}$ shoot (air-dry mass, g/ $0.5 \mathrm{~m}^{2}$ ).

Table 4. Effect of $\mathrm{N}$ levels on yield components at harvest in 1994 (chernozem loam soil with lime deposits, Nagyhörcsök, Hungary). Note: mean plant height: 77 $\mathrm{cm}$.

Table 5. Effect of $\mathrm{N}$ levels on the element contents of oat in 1994 (chernozem loam soil with lime deposits, Nagyhörcsök, Hungary).

Table 6. Effect of $\mathrm{N}$ levels on the B, Ba and Al content of oat in 1994, $\mathrm{mg} \mathrm{kg}^{-1}$ (chernozem loam soil with lime deposits, Nagyhörcsök, Hungary).

Table 7. Effect of $\mathrm{N}$ and $\mathrm{Cu}$ levels on the $\mathrm{Cu}$ content of oat in $1994, \mathrm{mg} \mathrm{kg}^{-1}$ (chernozem loam soil with lime deposits, Nagyhörcsök, Hungary).

Table 8. Effect of $\mathrm{N}$ and Mo levels on the Mo content of oat in 1994, $\mathrm{mg} \mathrm{kg}^{-1}$ (chernozem loam soil with lime deposits, Nagyhörcsök, Hungary).

Table 9. Mean composition and element uptake of oat in 1994 (chernozem loam soil with lime deposits, Nagyhörcsök, Hungary). Note: calculated in terms of $4.27 \mathrm{t} \mathrm{ha}^{-1}$ straw + husks, $2.92 \mathrm{t} \mathrm{ha}^{-1}$ grain.

Keywords: interactions, long-term experiment, oat, calcareous chernozem soil 